\title{
SOMETHING UNDERSTOOD: FORMALITY AND THE LANGUAGE OF THE HEART IN THE LETTERS OF SYLVIA TOWNSEND WARNER
}

\author{
Jan Montefiore
}

William Maxwell recorded that when he agreed to be Sylvia Townsend Warner's literary executor, she suggested that he might edit a collected volume of her letters. 'I love reading Letters myself, and I can imagine enjoying my own' (Warner, 1982b, p. xvi). That suggestion bore prolific fruit; $\mathrm{STW}^{1}$ is today known at least as well by her posthumously published correspondence as her fiction, poetry or music. In addition to Maxwell's 1982 edition of her letters, three volumes of her correspondence have been published: STW and David Garnett (1994), STW and Maxwell himself (2001), and the love-letters to and from Valentine Ackland, linked by STW's own narrative and edited by Susanna Pinney, her other literary executor (1998). All bear STW's hallmarks of wit, verbal elegance, deep feeling, and old-fashioned formality. The value she set on formal courtesy can be seen in a diary entry mourning her friend Leonard Bacon:

I have lost a confidant, a person to whom I could write quite freely without reservations, ... [like] people meeting at a masked ball 
who could speak with perfect intimacy and transgress nothing that should not be transgressed ... No-one to call me Charlie, Lamb lamented. I have plenty to call me Sylvia but no-one to call me Dear Miss Warner. (Warner 1994, p.205)

Penelope Fitzgerald rightly observed that STW's formality lies at the heart of her writing:

Her letters are formal in the sense that STW hardly knew how to write carelessly. It isn't that she is considering the effect; she produces one, from a long habit of elegance. She knew that herself. 'I can't say it yet,' she wrote to Leonard Woolf after his memoir Beginning Again came out. 'Already I am writing like a printed book, and falsifying my heart'.

(Fitzgerald, 2003, p.24)

This is very perceptive, but when that sentence is read in the context of STW's whole letter to Leonard Woolf, it no longer looks quite the confession of rhetoric masking feeling that Penelope Fitzgerald suggests it is. Here is the original letter:

Dear Leonard, Sowing and Growing in turn launched me into a sense of dialogue. As I read, I was talking to you in my mind, breaking off to follow a train of thought, recalling something that contributed. With Beginning Again I felt such concern, such an anguish of unavailing sympathy, that I could only sit in silence. That is why I have not written before. I have been sitting in silence for a fortnight.

There is so much else to say about the book; and not to acknowledge this would be 
to slight your total purpose and achievement. But I can't say it yet. Already I am writing like a printed book, and falsifying my heart.

(Warner, 1982b, p.212.)

The delicacy with which STW acknowledges Virginia Woolf's madness and Leonard's pain while avoiding any direct mention of either, shows how formality could actually deepen the intimacy of her correspondence. This is even clearer in an earlier letter to Leonard thanking him for having chaired her lecture to the Royal Society of Arts on 'Women as Writers'. She writes beforehand to their mutual friend the publisher Ian Parsons that she has been asked whom she would like as chairman for this lecture. 'Whom I would like is Leonard Woolf.' (Note that elegant accusative.) 'But do you think I could ask him? What daunts me a little is the thought that he might say yes out a sense of duty, \& kindness, and then have to spend an afternoon doing something that he would rather not' (Warner, 1982b, p. 169). Parsons must have reassured her, and after the lecture she writes to Leonard:

It was very kind of you to preside over me yesterday. It made me feel proud and enabled me to feel confident. I wanted to say at the beginning of the lecture that all women writers owe you a debt of gratitude for what you did for one particular woman writer. But I don't think these things should be said in public; so let me say it now. I have long wanted to. (Warner, 1982b, p.172)

The elegantly balanced chiasmus 'all women writers ...one woman writer' looks at first sight entirely suitable for the public tribute she had avoided giving. Why, then, did she not want to say this in public? Clearly not because of habitual English reserve, since she is saying it now. The reason for keeping it private is presumably her care for how Leonard might feel. Publicly praising him for having been a good husband to a writer of genius 
might have looked like belittling his own achievements; moreover, mentioning Leonard's care of his wife would unavoidably also have meant pointing, however indirectly, to her fragility and madness. Virginia Woolf's suicide in 1941 less than 20 years before STW gave her lecture in 1959, was a comparatively recent event from an ageing person's point of view (STW was then 65 and Leonard Woolf 78); and since the tragedy was common knowledge, even an indirect public allusion might have embarrassed and hurt him. These unsaid implications make STW's gesture of affection and gratitude not only courteous but extraordinarily, delicately intimate.

And yet that phrase 'falsifying my heart' has to give letter-readers and biographers pause. While letters represent an indispensable source of information about a life, even intimate ones are dubious evidence about the writer's self. Since any letter is addressed to a particular person, it is always affected by that person's response, or anyway by what the writer feels that response is likely to be. Examining the widely different epistolary selves presented by D.H.Lawrence in 1921 to his German mother-in-law, to Scofield Thayer the editor of the prestigious US magazine The Dial, and to his friend Earl Brewster (Ellis 2001, pp.124-8), David Ellis observes that

when people write letters they invariably adopt a tone and manner appropriate to the individual to whom they happen to be writing. They prepare a face to meet a face, as Eliot almost says. Even that notorious figure from English folklore, 'Disgusted, of Tunbridge Wells', is a different person when writing to his mother than when he is composing one of his indignant letters to the newspapers. Reading through a volume of letters to a variety of correspondents demonstrates that the most inflexible of individuals are changeable, different things to different people. (Ellis, 2001, p.124) 
STW the biographer of T. H. White knew this very well. Writing to the editor of White's letters to L.J. and Mary Potts, she described these as 'among the best of White's letters, and the most typical: bragging, confiding, asking for advice he won't take. In a way they are better than the letters to Garnett ${ }^{3}$, because they are without the desire to impress.'(Gallix, 1984, p.7) Although she lacked Lawrence's extraordinary variety of styles, she herself was almost as adaptable a correspondent as he was, her letters being characteristically full of the desire to give and to share pleasure - and again and again, as with those letters to Leonard Woolf, to avoid wounding. Ray Russell was wrong, I think, to assert in his otherwise perceptive review of the Warner/Maxwell correspondence that in reality both were writing with one eye on future publication... [though] the artificiality is more than made up for by the obvious enjoyment both had in writing the letters and receiving them' $(2001$, p.3). The fact that letters are performances, which many of STW's undoubtedly are, doesn't necessarily mean that they are aimed at posterity. Her best effects were often reserved for the appreciative eyes of friends who were also fellowwriters, like the letter telling Maxwell about going through some of her old diaries where she

found this record of a dream. 'The choir were singing:

Venus of her teeth disarming,

Teach a newer way of charming.

It was from one of Handel's oratorios. The oratorio was called Galahad'.

Isn't it sad that one never adequately meets one's dreaming self?

(Steinmann, 2002 p.162).

Even better is the long letter thanking Alyse Gregory for her Christmas present of a decorated matchbox:

Dearest Alyse, 
Usually one begins a thank-you letter by some graceless comparison, by saying, I have never been given such a very scarlet muffler, or, This is the largest horse I have ever been sent for Christmas. But your matchbox is a nonpareil, for never in my life have I been given a matchbox. Stamps, yes, drawing pins, yes, balls of string yes, yes, menacingly too often; but never a matchbox. Now it has happened I ask myself why it has never happened before. They are such charming things, neat as wrens...

But what I like best of all about my matchbox is that it is an empty one. I have often thought how much I should enjoy being given an empty house in Norway, what pleasure it would be to walk into those bare wood-smelling chambers, walls, floor, ceiling, all wood ... And when I opened your matchbox which is now my matchbox and saw that beautiful clean sweet-smelling empty rectangular expanse it was exactly as though my house in Norway had come true; with the added advantage of being just the right size to carry in my hand. I shut my imagination up in it instantly, and it is still sitting there, listening to the wind in the firwood outside. Sitting there in a couple of days' time I shall hear the Lutheran bell calling me to go and sing Lutheran hymns while the pastor's wife gazes abstractedly at her husband in a bower of evergreen while she wonders if she remembered to put pepper in the goose-stuffing; but I shan't go. I shall be far too happy sitting in the house that Alyse gave me for Christmas.

$\mathrm{Oh}$, I must tell you I have finished my book ${ }^{4}$ - begun in 1941 and a hundred times imperilled, but finished at last. So I can give 
an undivided mind to enjoying my matchbox.

PS There is so much more to say...carried away by my delight in form and texture I forgot to praise the picture on the back. I have never seen such an agreeable likeness of a hedgehog, and the volcano in the background is magnificent.

(Warner, 1982b, pp.94-95).

Much shorter but equally delightful is an exchange with William Maxwell inspired by his small daughters Brookie and Kate:

WM to STW, 17.9.1962: Brookie has named one of her paper dolls after you. Your name comes up sufficiently often in conversation between Emmy and me, and Brookie, playing on the floor, gathered up a name and went off with it. Except that you have to allow for what happens to things that pass through a child's mind. The doll's name is Cynthia Townville, but Kate assures me that it is named after you, and she should know.

STW to WM, 25.9.62: Oh, I am delighted to be Cynthia Townville! She sounds like the heroine of a late 18th cent. comedy, an heiress with a muff and an enormous Duchess of Devon hat, who will subdue the rake \& then marry him.

(Steinman, 2001, p.121).

These fantasies sparked off by small things demonstrate not just the wit, fantasy, elegant command of language and learning lightly worn displayed in the plot summary of 'Cynthia Townville' and the elaborate scenario of church ending 'but I shan't go', but STW's warm responsiveness. She writes almost as if Alyse 
Gregory and the Maxwell family had themselves given her the cosy scene in the Norwegian church and the imagined eighteenth-century comedy which are in fact her own verbal presents to them. Writing 'with one eye on publication' would have taken the spontaneity and intimacy out of her correspondence and for all her eighteenth-century elegance and formality, STW set a high value on spontaneity. Look, for instance, at her lyrical inventory of the pleasures of autumn in her 1968 letter to David Garnett, written while her lover Valentine's terminal breast cancer, which Garnett knew about, was in remission.

I have harvested my garlic - a splendid crop. I have made rowan jelly, from which proceeds grouse - a promising grouse casserole simmers in the kitchen. Red Admirals loiter about the garden, and a mole tunnelling under a path obligingly sends up heaps of the best potting earth. I wish it were always September. Even apart from Keats this is the time of year I am happiest in though I only discovered why this very morning. Spring is rather a bitch. It insists on being waited for, keeps one at a stretch, stings like a young nettle. Autumn just arrives and embraces, no fuss, no proclamation. It is like being looked at by Ray.

(Garnett, 1994, p.147).

She couldn't have written that last sentence to anyone else. Other literate readers could have picked up the allusion to Keats' Ode to Autumn', but only Garnett would have heard the muted note of grief and foreboding. Ray Garnett, David's first wife and Sylvia's own close friend, had died in 1940 of breast cancer.

STW could write such poignant, witty or inventive letters to Maxwell and Garnett because she knew they were splendid readers. They returned the compliment by writing back as well as herself - or almost as well, for out 
of the three published correspondences, only David Garnett's letters to Sylvia seem to me consistently as good as hers to him. He writes in his own plain style, whereas Valentine Ackland and even William Maxwell occasionally sound just a little like Sylvia-and-water.

As Margaretta Jolly has argued, the formal reserve of STW's correspondence with David Garnett can be very moving, especially in their exchanges after Valentine's death. Instead of her usual endearment 'Dearest David', STW addresses him formally: 'Dear David, Valentine died on the ninth of November. You will know too well how I have felt.' She adds that she intends 'to stay here, alone' but hopes to see him if ever he comes to Dorset (Garnett, 1994, p.155). Garnett answers as gravely: 'Dear Sylvia, I send you my love', saying that he himself finds consolation in remembering that the beauty of the visible world goes on existing

whereas we don't. But such reflections are no help for pain and loneliness: for that there's no cure, my dear. Well, all my love.

(Garnett, 1994, p.155)

Months later, STW thanks him for speaking the plain truth:

I was grateful to you for your letter after Valentine's death, for you were the sole person who said that for pain and loneliness there is no cure. I suppose people have not the moral stamina to contemplate the idea of no cure; and to ease their uneasiness they trot out the most astonishing placebos. I was assured I would find consolation in writing, in gardening, in religion, in tortoises, in tapestry, in doing another book like the White biography, in keeping bees, in social service (the world is so full of misery); and many of these consolers were people whom I had previously found quite rational.

(Garnett, 1994, p.156) 
We needn't doubt, however, that Sylvia had thanked these would-be consolers charmingly.

It is clear from this exchange that it can be easier, and clearly was for these two, to be honest about one's own pain and loneliness when writing to a friend than when meeting face to face. But as Margaretta Jolly says, the value of their stoical correspondence has to be 'measured by the costs as well as the pleasures of standing alone' (Jolly, 2007, p.28). And sometimes, their readers need to work things out from what the writers don't say. Jolly instances the discrepancy between STW's 1959 letter of warm praise to Garnett about his novel $A$ Shot in the Dark which his publisher rejected for indecency, and her affectionate but much cooler diary entry about him. Even more striking is the discrepancy between what she wrote to and about Garnett after she came from Dorset to visit him at Hilton Hall after his second wife Angelica left him in 1962. They met on Cambridge station.

30.iv.62: David was on the platform, looking in the wrong direction. As I approached I saw him and the look was frantic and foiled: as much as to say: This is going wrong. We drove soberly along almost empty roads and he correctly made me tea ... All this while David was cooking. He is still riddled with shock, and talks slower than ever, and though we were all gay at dinner there was a sensation of how well we were keeping it up - except William ${ }^{5}$ with his tranquillity like Ray's: a deer about the house.

2.v.66: Inevitably, I suppose, I left feeling I should not go there and find him again. But he is working on another book, so perhaps that will rebuild his interior.

(Garnett, 1994, p.102)

Here is her thank-you letter for the week-end, written the same day: 
Darling David,

My mind is full of space and trees and happy young creatures - and friendship. It was a lovely week-end; you are the most comfortable of hosts. I could even say 'Down, wanton, down!' to my restless conscience, which felt it should be expressing itself in the sink. It couldn't urge me to cookery because you cook so extremely well - and so unobtrusively, the mark of the master.

(Garnett, 1994, p.102).

It would of course be absurd to call the letter hypocritical because it contradicts the diary; it is a model of discretion and kindness, not to mention ordinary good manners from a properly appreciative guest. Rather than telling Garnett that she has seen how shattered he is which would have been crassly wounding - she writes to strengthen her old friend's resilience, both by showing her affection and loyalty and by her implied reminder that his life does still hold the pleasures of cookery, conviviality and family warmth. As Garnett and Warner get older this conjunction of desolation at the loss by death or estrangement of loved people and animals with their shared determination to enjoy life's pleasures, especially food and friendship, gets more and more marked.

The discrepancies in STW's correspondence with Valentine Ackland are more complex, and, as Terry Castle has argued, not always so creditable. The couple wrote to each other constantly (two or three times a day when apart, and sometimes every day even when living together) and voluminously. Although Susanna Pinney has edited the correspondence down to a third of its original 400,000 word length, I'll Stand By You (1998) still takes up 392 pages of passion, affection, humour, tenderness, assurances of affection, and anxious advice on the lines of 'Look after yourself'. (There is so much of this last that the writers sometimes sound like Pont's 
cartoon woman raising her hands to entreat 'Darling, you must PROMISE me you won't catch cold': Pont, 1942, p.81). Their letters in the years after their disastrous ménage a trois with Elizabeth Wade White in Connecticut in August 1939 are especially full of solicitous assurances. On 'Valentine's day' 1941, Valentine writes eponymously: 'I am so very glad to be free to love you again as completely as $I$ had loved you for eight years...I do love you, I do most truly and passionately love you.' Recalling their early love during the years in East Chaldon, she assures Sylvia that it is all as bright and rich as it was then' (Pinney, 1998, pp.192-3). If while reading this we wonder, 'Then why does she need to go on and on about it so much?' a few pages and eight years later we find out when in May 1949 Elizabeth arrives from the USA, and their affair flares up again. Valentine writes lyrically in her journal about their three days of lovemaking

in a large dark bedroom at the Kings Arms, Dorchester...everything happened; we were completely and irrevocably restored to each other, with greater happiness and completion than we had ever imagined...As a result of being raised from the dead (meaning that my body has come alive again, after being entombed for about 10 years), I am dissipated, scattered...

(Pinney, 1998, p.227)

We thus discover that Valentine may have loved Sylvia deeply but certainly not 'passionately' in the sense most people use this word, since she stopped desiring her sexually in 1939. In a letter written after the crisis was over, Sylvia explains to Valentine that she had accepted the other's withdrawal because she thought it best not to probe:

Seeing you so ravaged after U.S.A. and knowing your physical love for me was 
blighted, a kind of frost fell on me too. I did not want to remind either of us of how it had been.

(Pinney, 1998, p. 281)

Sylvia is nevertheless much the braver of the two about facing hard facts; Valentine never writes to her with such clear-eyed honesty.

This retrospective letter was written from London, after Sylvia had successfully refused to allow Elizabeth to become a permanent fixture in their lives. Earlier that autumn she had moved out of their house in Maiden Newton in order to leave Valentine and Elizabeth alone to enjoy their affair through the month of September. During this period of exile she and Valentine wrote to each other constantly and snatched occasional clandestine meetings, as if they were illicit lovers and Elizabeth a betrayed wife. One would never guess from Sylvia's long charming letters to Valentine how much pain she was undergoing in the month of absence which she privately called 'my ancient solitary reign ${ }^{6}$ (Warner, 1994, p.138). Staying in the second week of her exile with their close friend Alyse Gregory, the widow of the writer Llewellyn Powys, she writes to Valentine,

I am living in the extreme of luxury. Alyse brings me my breakfast tray to the shelter, with an outdoor peach on it... Chydyok has changed its colours since we saw it last. Projects have become performances, seedlings have become trees. It is strangely romantic to see Llewellyn's medlar-tree, in its tapestry of dark fruit and dark leaves, against the bare sweep of the field, and to turn one's eyes from the old barn to the clusters of grapes on the vine.

(Pinney, 1998, p.252).

Sylvia's journal entry for the next day muses

My myrtle, the Miss Green myrtle ${ }^{7}$ I gave Llewellyn, is growing in the garden. Strange 
to see. And the dusky tapestry green and brown of his medlar tree against the hillside. Den allen schuld recht sich auf erden ${ }^{8}$. I understood that, this evening, lying in deep misery, thinking of a passage in Valentine's letter about how she in her love with Eliz: can live innocently - and that it is because I am steadfast and 'completely without guile or reservation.' Recht sich auf erden. She lives and loves innocently with Eliz: because I am shaken by fears and doubts, ravished with physical and mental jealousy, and steadily murder myself in concealing it. (Warner, 1994, p.142)

Unlike the differences between STW writing to and about David Garnett in 1966, this discrepancy shows the costs as well as the pleasures of discretion. Read in the light of the diary entry, Sylvia's evident wish to protect Valentine by avoiding even a hint of her own pain and loneliness looks at this point less like kindness than masochistic complicity and self-betrayal. And Sylvia knows it: 'Recht sich auf erden', presumably meaning that Valentine's infidelity is a just punishment for her own sin of dissimulation. Her bitter statement 'I am ravished with physical and mental jealousy, and steadily murder myself in concealing it', shows that she is only too well aware that this dissimulation risks corrupting her relationship with Valentine, and perhaps has already done so. In 1950, when the crisis has passed but Valentine and Elizabeth are still dithering about what to do, Sylvia writes in her diary after a conversation with Valentine: 'She deceives herself about me far more than $I$ deceive her' (Warner, 1994, p.161 ) - not something she would ever write to Valentine.

None of this, however, means that the diary-entry reveals the 'real' pathological nature of the love between Sylvia and Valentine which they so often avow in their letters. Reality is more complex and contradictory than that. Sylvia's relatively happy or at least equable letter to 
Valentine is not entirely deceptive because, like all loveletters, it makes the beloved present by 'creating' her in its own textual space. Roland Barthes writes illuminatingly about this process in the entry 'Absence' in A Lover's Discourse:

In the other's absence, the Other is absent as referent, present as allocutory. From this singular distortion, a kind of insupportable present emerges: you are gone (which I grieve for), you are there (since I address you). I know then what is the present, that difficult tense: a pure portion of anxiety.

(Barthes 1977, p.21: my translation)

Half the point of writing a love-letter is to annul this present-tense anguish through the textual fantasy of the Other's presence, at least for the moment of writing (the beloved's corresponding experience in the moment of reading is the other half.) So Sylvia writing to Valentine felt herself loving and loved - which wouldn't stop her from being racked with sexual jealousy and self-reproach when lying in bed alone the next day, or from being even more tortured when she wrote of her bitterness in her diary that evening. For as David Ellis correctly says, even private journals 'are audience-directed, even if the audience concerned is God or that ideal readership of a few specially selected dead people which Stendhal imagined for his Sonvenirs d'égotisme' (Ellis, 2001, p.127). STW (who, incidentally, much admired Stendhal) writes so bleakly in her journal because there she describes her own 'deep misery' as if to a third party who knows what her own jealousy and her silence about it are costing her, rather than to Valentine who so 'innocently' trusts in Sylvia's unconditional love. Yet the Sylvia who just before exiling herself wrote to Valentine with splendid, eloquent certainty, 'You are as much mine as I am yours. Not only can I have no doubt of your love for me, I have no doubt of my love for you, no doubt that it is right, no doubt that you demand it and require it' (Pinney, 
1998, p.238), wrote quite as truly as the lonely diarist lamenting her 'ancient solitary reign'. Perhaps even more truly, for as she prophesied, their mutual love endured for better and worse, as long as both women lived.

The enduring enchantment of STW's letters, then, is the way they communicate her personality - not just her wit, fantasy and elegance but her warmth and her honesty about her feelings; she may sometimes have spared her correspondents (especially Valentine) from hearing harsh truths, but she didn't spare herself. Much though I admire Margaretta Jolly's 'A Word is a Bridge', I cannot entirely agree with her conclusion that STW's correspondences show how 'though we are not autonomous, we can only cross that bridge alone' (Jolly, 2007, p.30). Despite their implicit absences and their occasional lies by omission, all of STW's letters speak her presence in a relationship, whether she writes a thank-you for a present or for hospitality, a fantasy, a dream, a story, a reassurance or a declaration of love as moving as George Herbert's 'Prayer',

the soul's blood,

The land of spices, something understood.

\section{NOTES}

1. I am following Maxwell's practice of referring to Sylvia Townsend Warner the writer as 'STW' (Warner, 1982, pp.xiv-xv), because 'Sylvia' sounds too familiar and 'Warner' too abrupt for a writer who habitually used all her three names. When discussing her love-letters to Valentine Ackland I do, however, refer to her as 'Sylvia' because using initials would here feel too impersonal.

2. Beginning Again deals with the events of 1911-18 including Leonard Woolf's marriage to Virginia Stephen in 1913 and her subsequent breakdowns in 1913 -14, as well as the First World War.

3. T.H.White's correspondence with David Garnett had been published as The White/Garnett Letters in 1968

4. The Corner That Held Them (1948). 
5. William Garnett b.1925.

6. From Gray's Elegy in a Country Churchyard stanza 3: 'The moping owl doth to the moon complain/ Of such as, wandering near her secret bower,/ Molest her ancient solitary reign'.

7. 'Miss Green' was STW and VA's name for the small house in East Chaldon where the couple first discovered their mutual love. It had been described by the estate agent from whom STW bought it as 'the late Miss Green's cottage'.

8. 'All $\sin$ is punished here on earth': Goethe, Wilhelm Meister

\section{WORKS CITED}

BARTHES, R. (1977) Fragments d'un discourse amoureux, Paris, Editions du Seuil. CASTLE, T. (2002) 'The Will to Whimsy', Boss Ladies, Watch Out! Essays on Women, Sex and Writing New York, Routledge.

ELLIS, D. (2001) 'Letters, Lawrence, Shakespeare and Biography', Journal of European Studies Vol. 32, 2\& 3, June/ September 2001, 'Lives and Letters' Eds. Jan Montefiore and Nicky Hallett, pp.121-134. FITZGERALD, P. (2003), A House of Air: Selected Writings London, Flamingo.

GALLIX, F. Ed. (1984) Letters to a Friend: the Correspondence between T.H.White and L.J.Potts Gloucester, Alan Sutton.

GARNETT, D. (1968), The White/Garnett Letters, London, Cape.

GARNETT, R. Ed. (1994) Sylvia \& David: The Townsend Warner/ Garnett Letters London, SinclairStevenson.

JOLLY, M. (2007), 'A Word is a Bridge', Journal of the Sylvia Townsend Warner Society pp.18-30.

'PONT' [Graham Laidler] Pont, London, Collins 1942. RUSSELL, R. (2001), 'Book Review', Sylvia Townsend Warner Newsletter No. 2, p.3. 
PINNEY, S. Ed. (1998), I'll Stand By You: The Letters of Sylvia Townsend Warner and Valentine Ackland London, Pimlico.

STEINMAN, M. Ed. The Element of Lavishness: Letters of Sylvia Townsend Warner and William Maxwell Washington D. C., Counterpoint Press.

WARNER, S. T. (1948), The Corner That Held Them London, Chatto \& Windus.

. (1982a) 'Women as Writers', Collected Poems Ed. Claire Harman, Manchester, Carcanet, pp.265-274, (reprinted from the Journal of the Royal Society of Arts, May 1959, pp.378-86).

. (1982b), Letters Ed. William Maxwell. London, Chatto \& Windus.

(1994) The Diaries of Sylvia Townsend Warner Ed. Claire Harman. London, Chatto \& Windus.

WOOLF, L. (1964), Beginning Again: A Memoir of the Years 1911-1918 London, Hogarth. 